\title{
From Agriculture to Mining: The Changing Economic Base of a Rural Economy and Implications for Development
}

Abstract: $\quad$ This paper uses economic-base theory and input-output modelling to examine the structure of a regional rural economy in New South Wales, Australia, drawing important policy implications for economic planners. The most salient trend has been a shift in the area's dependence from agriculture to mining over the recent decade. However, the level of diversity of the region's industrial composition has altered very little. Mining is also contributing to significant net leakage of employment income from the region. Mining should therefore not necessarily be considered as the key future opportunity for economic development. Instead, a number of industry sectors, particularly those that foster innovation and technology, can be harnessed to drive future regional growth. In addition, a tourism marketing strategy promoting the region's food, wine and other distinctive attributes should play an integral role in future development planning. These prescriptions are highly transferable to similar rural economies experiencing a shift to mining.

Keywords: Agriculture, Central West, NSW, Australia, economic base, diversity, mining, tourism JEL codes: J61, J68, Q32, O15, R12, R23

\section{INTRODUCTION}

The ever-growing concentration of population in urban areas, coinciding with low and declining rates of growth in regional areas, has reignited debate over the relative advantages of different approaches to regional development (Dubé \& Polèse, 2014; Thompson \& Maginn, 2012; McManus, et al., 2012; Johnson, 2001). These increasing disparities in growth rates can arguably be attributed to economic, social and technological changes on a global scale (Rodrik, 2008; SGS Economics and Planning, 2008) which have contributed to changes in the economic structure and intensities of diversification within regional areas in many countries (Delgado, Porter \& Stern, 2014; Hvidt, 2013; Organisation for Economic Co-operation and Development, 2013).

The agricultural sector has long been seen as a key contributor to the growth of developing countries in Europe, the United States, Canada and Australasia; however, the growth of other industries in recent decades has seen a relative decline in these countries' reliance on agriculture (Banks, 2010) with a shift in reliance to mining for economic growth (Sheng, et al., 2015; Haslam McKenzie, et al., 2013; Productivity Commission, 2005).

The evidence for mining playing a pivotal role in the recent economic performance of many regional economies, despite the rhetoric (Measham et al., 2012), is in part difficult to determine because information on impacts to regional economies from temporal changes in industry composition is limited. For example, studies in North and South America suggest a resource rollercoaster effect (Wilson, 2004) with considerable oscillations in wellbeing in line with shifts in commodity prices and other macro-economic conditions (Caselli \& Michaels, 2013; Halseth, 2005). 
Much has been written concerning economic sustainability in other regions across the globe. However, there has been very little written on industrial composition that promotes economic resilience and sustainable growth consistent with Australian's regional industrial attributes (Beer and Clower, 2009; Bradley and Gans, 1998; Dixon and Freebairn, 2009; Koo, 2007). This paper investigates the shifting nature of this industrial composition to provide policy advice to decisionmakers and economic planners. To do this we explore three salient research questions applied to the Central West Region of New South Wales, Australia as an example: (i) Has there been a shift in the region's economic dependence from agriculture to mining? (ii) Has the industrial structure of the regional economy become more or less diverse over the most recent decade? (iii) Are there identifiable sectors of the economy where future investment may help underpin the region's economic viability?

The remainder of the paper consists of six sections. Section II introduces Economic Base Theory, how it has evolved, and why it is important to analysing the shifting structure of regional economies. This section also introduces the concepts of specialisation and diversification which are important elements to the theory and practice of regional economic development. Section III briefly introduces the case study region. Section IV outlines the data and methodologies employed to analyse the economic structure and diversity of the case study region. Section V presents the results and section VI provides a discussion including policy implications for similar regional economics. The paper ends with some concluding remarks in section VII.

\section{ECONOMIC BASE THEORY}

Critical to understanding the shifting nature of regional economies is economic base theory (EBT) (Nelson, Drummond \& Sawicki, 1995; North, 1955). EBT began in the previous century with Haig's (1926) instrumental work demonstrating the changing nature of New York's economy through the segmentation of employment into ten main industrial groups over a given time period. This work in part helped economic planners develop New York into the iconic city it is today.

In the latter half of the previous century, EBT has been combined with community demographics to help analyse local and regional economic instability (Shields, 2003; Smith \& Gibson, 1988; Attaran.1986). For example, Rodgriguez-Pose \& Gill (2006) compared the manufacturing and agriculture industry sectors within eight major world economies and found that as agricultural exports became less important than manufacturing exports, regional instability increased. When agricultural exports became more significant, regional instability declined.

\subsection{Regional Economic Diversity versus Specialisation}

Related to EBT and the study of regional industrial structure is the question of whether diversification or specialisation facilitates economic growth. At the core of the argument is whether the most innovative and fast-growing areas are sectorially specialised or diversified (Van Oort, de Geus \& 
Dogaru, 2014; Iammarino \& McCann, 2013; Duranton \& Puga, 2000). Regional economic diversity refers to the variety of industrial mix within a region, often measured as the degree to which employment rests within a diversified range of industries. The less varied the employment structure of a region, the more specialised are the region's industry sectors (Siegel, Johnson, \& Alwang, 1995). As noted by Trendle (2006, p.768) "regional economic theory suggests that greater diversity will make regional economies more stable". The implicit assumption is "that a diverse regional economy will enjoy a stable employment growth rate, with the diversity acting to shield the regional economy from fluctuations in the market for its products" (Trendle, 2006, p.768; Malizia \& Ke, 1993). Such economies enjoy secure employment, income and living standards (Dissart, 2003) because small firms significantly drive regional industrial diversification (Keniry, 2003). These firms alleviate community dependence on limited industries that would otherwise leave a region susceptible to employment and population loss during periods of economic downturn (Regional Australia Institute, 2013).

In contrast, Porter's (2000) cluster theory argues that regionaf specialisation contributes to economic growth, building on Krugman's (1991) prognosis that regional economies should specialise over time to deliver economic growth. Porter (2000, p.16) defines a cluster as "a geographically proximate group of interconnected companies and associated institutions in a particular field, linked by commonalities and complementarities".

\section{THE CASE STUDY REGION}

The Central West region in New South Wales (NSW), Australia is depicted in Figure 1 along with its Local Government Areas. The importance of agriculture's contribution to growth in the region has recently been underscored by the Australian Federal Government's commissioning of the Agricultural Competitiveness White Paper, aimed at boosting agricultural productivity and profitability (Thomas, Hamilton, \& Stephens, 2014) not just in the Central West but across most of regional Australia. 
Figure 1: Map of Central West Region and its Local Government Areas

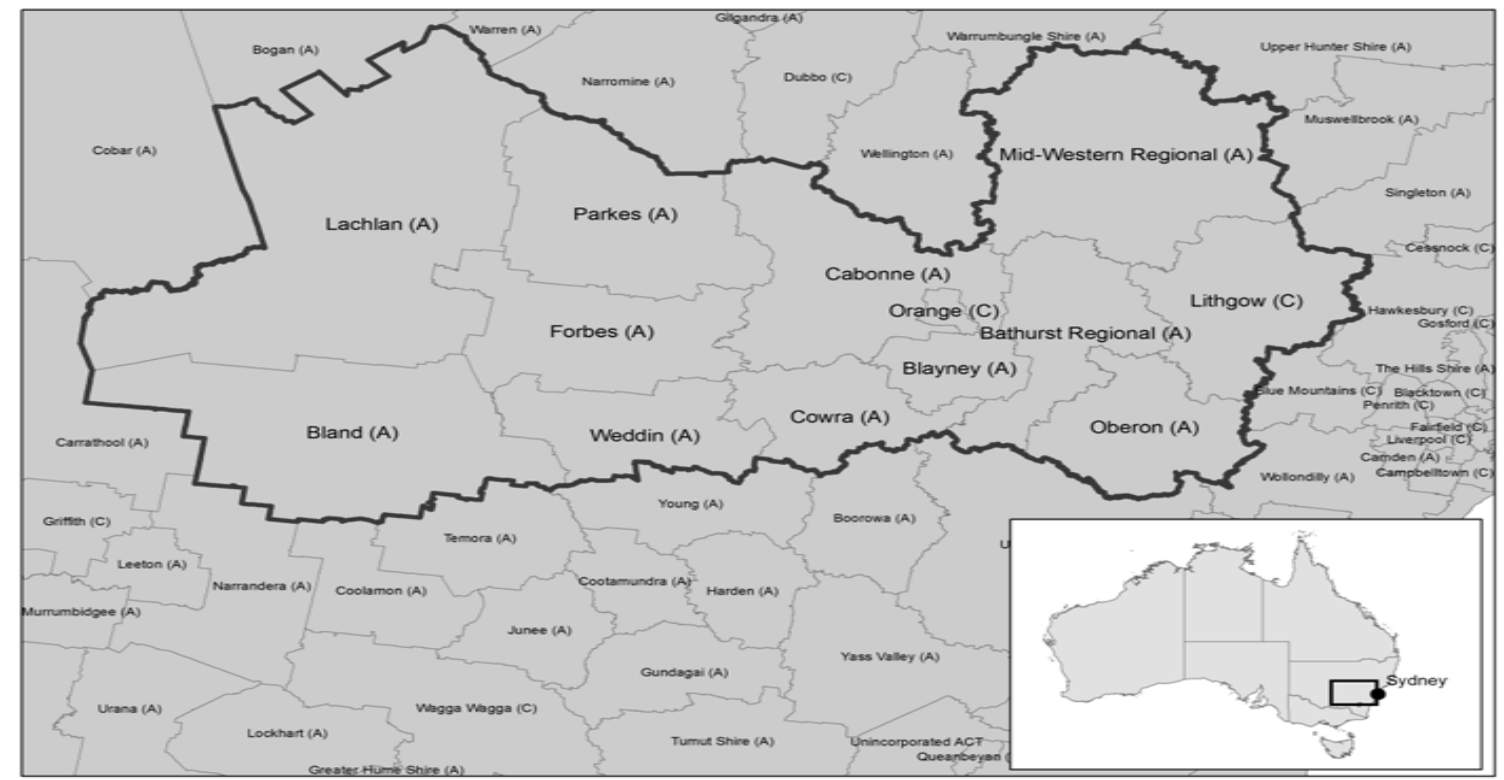

Source: Prepared by [insert name], 2014, [insert institution] using ArcGIS.

\section{DATA AND METHODS}

The data drawn (Table 1) for this research were from a number of Australian Bureau of Statistics' sources and these were used to calculate the measures of population, employment, work commuting and demography of the Central West region and each of its Local Government Areas. Central West input-output (I-O) tables were also constructed from data derived from the national accounts. Consistent application of I-O measures from the tables allowed for both temporal and spatial comparisons to be made. Additionally, coefficients of regional specialisation, changes in employment, measures of service delivery, were prepared using Census employment data for 2001 and 2011.

Table 1: Measures, Methods and Sources

\begin{tabular}{lll}
\hline Measure/Method & $\begin{array}{l}\text { ABS 1981 and 2011 source } \\
\text { (unless otherwise noted) }\end{array}$ & Reference \\
\hline Population and Employment & $\begin{array}{l}\text { Census of Population and } \\
\text { Housing }\end{array}$ & (Australian Bureau of Statistics, 2013a) \\
Commuting to Work & $\begin{array}{l}\text { Census of Population and } \\
\text { Housing }\end{array}$ & (Australian Bureau of Statistics, 2013a) \\
& $\begin{array}{l}\text { 2011 Age Profile (cat. no. } \\
\text { Demographics }\end{array}$ & (Australian Bureau of Statistics, 2013b) \\
& 3235.0) & \\
\hline Central West I-O tables (I-O) & $\begin{array}{l}\text { Census of Population and } \\
\text { Housing }\end{array}$ & (Australian Bureau of Statistics, 2013a) \\
\hline $\begin{array}{l}\text { Coefficient of Specialisation (CS) } \\
\text { Service Delivery (PER) }\end{array}$ & $\begin{array}{l}\text { Census of Population and } \\
\text { Housing }\end{array}$ & (Australian Bureau of Statistics, 2013a) \\
\hline
\end{tabular}

Sources: a. Australian Bureau of Statistics, 2013a; b. Australian Bureau of Statistics, 2013a 


\section{RESULTS}

\subsection{Population and Employment}

Table 2 shows that the resident population of the Central West was almost 10 per cent higher in 2011 than it was in 1981. Over the same period employment grew by around 18 per cent, reflecting an increase in the share of the resident population locally employed of over three per cent.

Table 2: Central West Population and Employment

\begin{tabular}{cccc}
\hline Year & Population (no.) & Employed (no.) & Employed (\%) \\
\hline 1981 & 178,350 & 72,432 & 41 \\
1986 & 180,040 & 69,551 & 39 \\
1991 & 186,820 & 71,944 & 39 \\
1996 & 189,899 & 75,440 & 40 \\
2001 & 188,766 & 78,796 & 42 \\
2006 & 188,575 & 80,390 & 43 \\
2011 & 195,819 & 85,835 & 44 \\
\hline
\end{tabular}

Source and notes: Calculated from Australian Bureau of Statistics (2013a)

\subsection{Commuting To Work}

Figure 2 shows overall a higher net income leakage from the number of people commuting into the Central West for work rather than commuting out, with mining being primarily responsible for incoming workers. Net employment leakage can reduce a region's economic development and is characteristic of Core-Periphery staples theory in other regional economies (e.g. see Blackwell et al. 2015; Carson, 2011.) and because mining workers on higher incomes can choose where they prefer to live (Blackwell et al. 2015). Associated with mining, construction was also responsible, driven by increased demand for local housing and mining's expansion (Rolfe, et al., 2007). 
Figure 2: Net Commuting, Central West 2011.

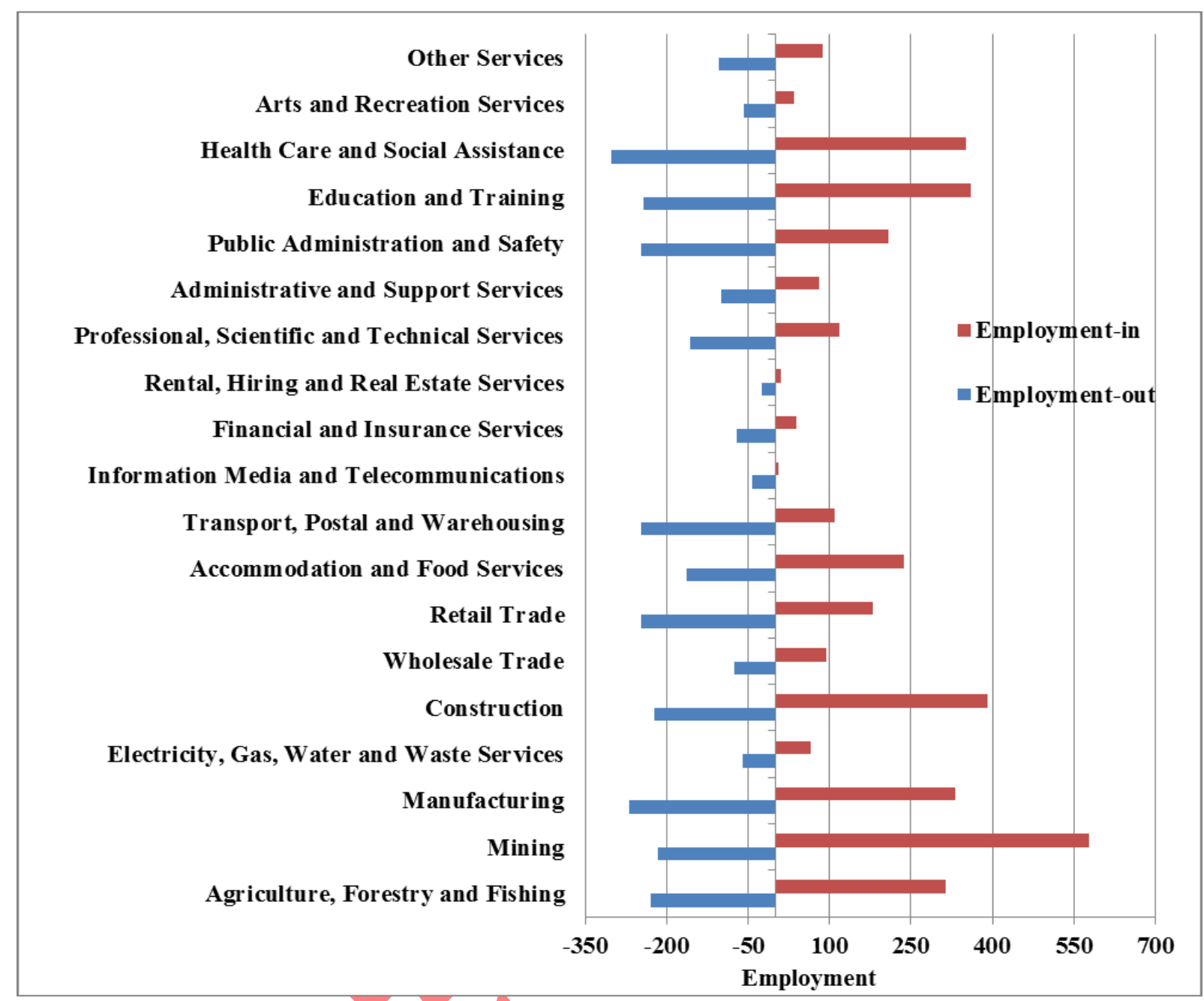

Source and notes: Calculated from Australian Bureau of Statistics (2013a)

\subsection{Demographics}

Figure 3 illustrates that while young people up to the age of 19 have a greater representation in the Central West, people aged from 20-39 are under-represented. This most likely reflects the desirability for younger adults to pursue a range of opportunities in capital cities, including education, employment and entertainment (Trendle, 2009). Combined with an exodus of younger people the region also has a greater proportion of people aged 40 and over. 
Figure 3: Age Profile of the Central West Population, 2011.

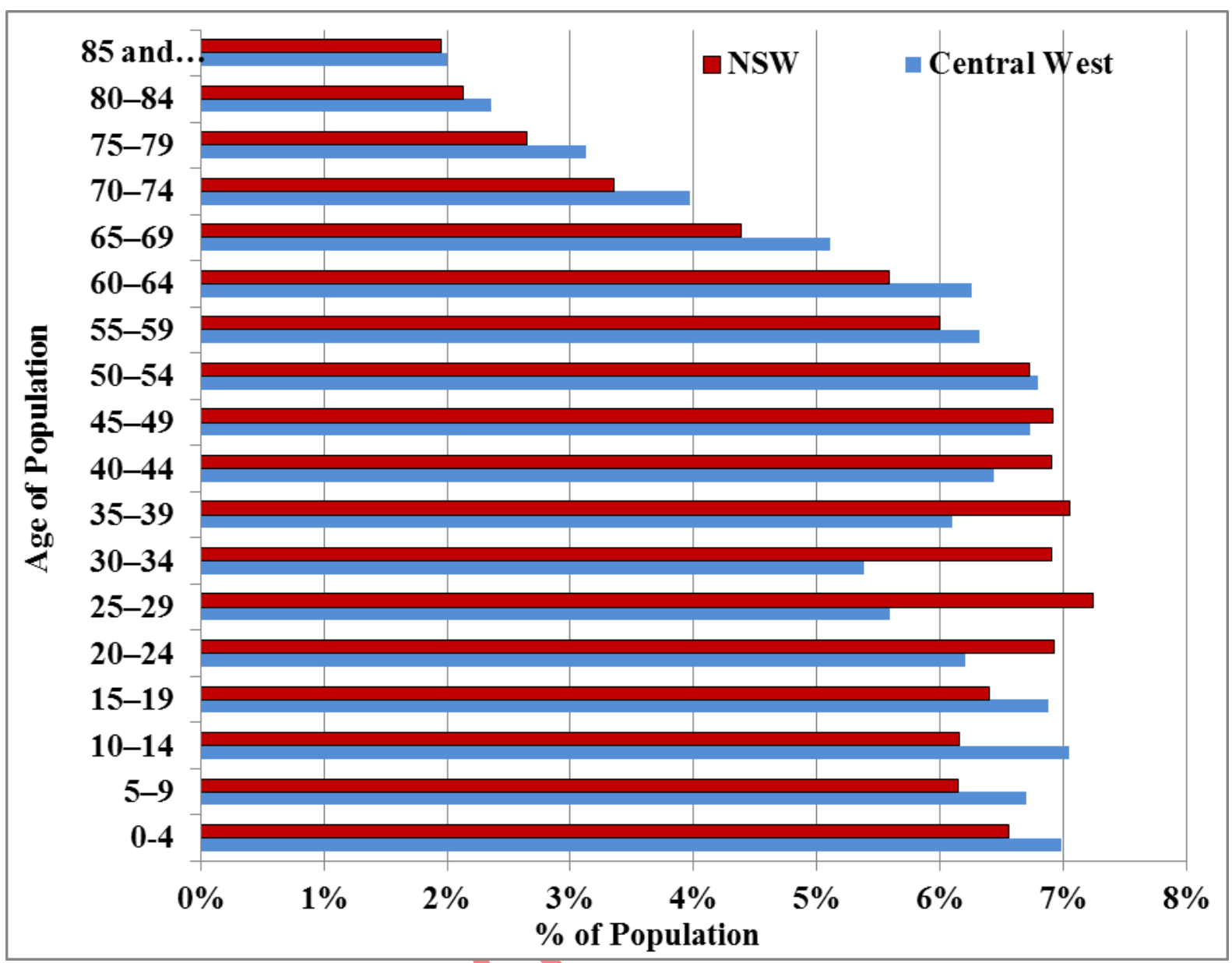

Source: Australian Bureau of Statistics (2013b).

\subsection{Industry Structure}

Figure 4 shows the increasing dominance of the mining sector and corresponding declines in the agriculture, manufacturing, utilities and trade and accommodation sectors in the Central West economy over 2001 to 2011. The building, business services, and public and personal services sectors also grew, with particularly noticeable employment gains in the public and personal services sector.

In 2001 the region had a large manufacturing export base which, along with the agriculture sector, has fallen considerably in 2011. The building industry exhibited modest increases in employment over the period, most likely related to the increased local mining activity (Fleming \& Measham, 2015). The agriculture, forestry, fishing, and manufacturing sectors experienced notable declines in employment over the decade. Overall, the service sectors were the main employers within the region and the largest contributors to local GRP. However, the increasing importance of the mining sector is evident, accounting for approximately 20 per cent of GRP in 2011. 
Figure 4: Industry Structure of the Central West Region Economy.

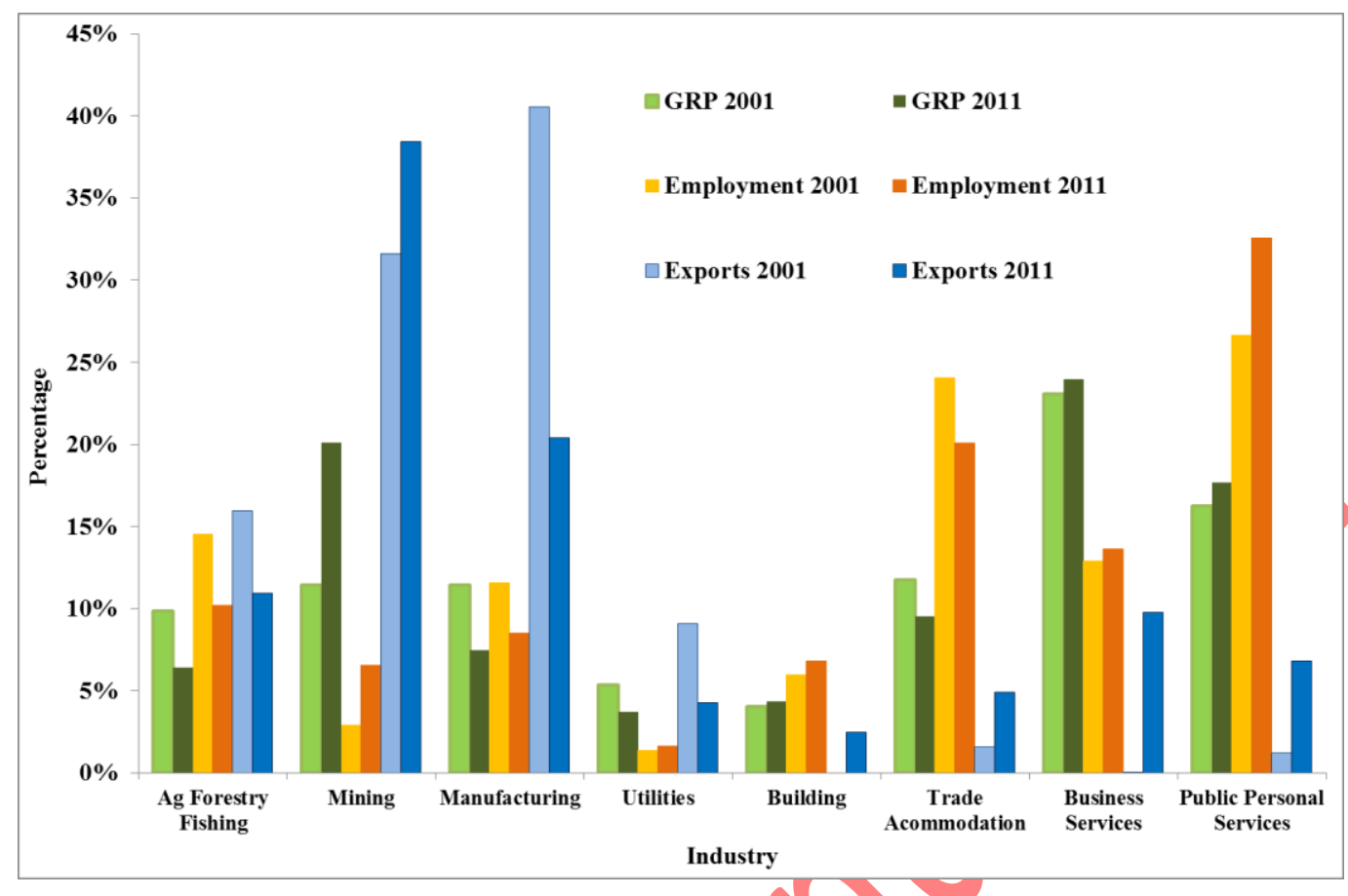

Source and notes: Calculated from the 2001 and 2011 Central West I-O tables (ABS 2013a).

\subsection{Regional Specialisation and Diversification}

Figure 5 shows that between 2001 and 2011 the Central West de-specialised or diversified slightly, with a drop in manufacturing being an underlying factor and despite employment in the local mining industry expanding by 162 per cent (see Table 4). In comparison, there was a small increase in specialisation for NSW (Figure 5) relative to Australia. 
Figure 5: Measure of Economic Specialisation.

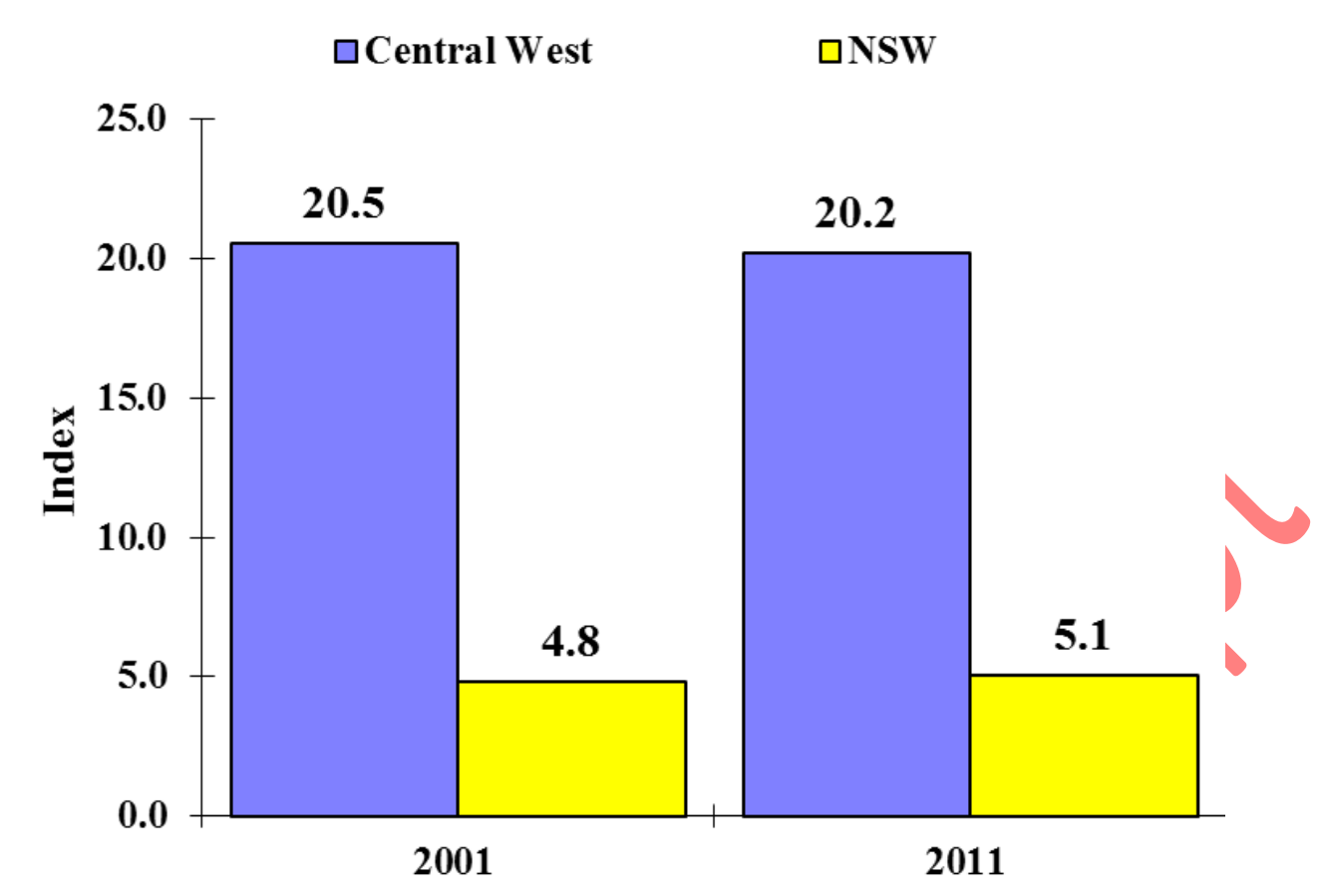

Source and notes: Calculated from Australian Bureau of Statistics (2013a)

\subsection{Service Delivery}

High service delivery sectors in the Central West in Figure 6 include accommodation, public administration and regulatory services, and residential care and social assistance services. Also, there was a large increase in the repairs and maintenance industry ratio while significant declines are evident for rail transport, and the gambling, and sports and recreation sectors.

Noticeably underserviced areas in the Central West include telecommunications which supports new businesses and particularly the professional, technical and scientific services sectors, critical sources of research, development and innovation (Trendle 2009, Salomon, 1997). Employment resources could potentially be redirected to the health care service area as highlighted by its below parity and declining seryice delivery ratio. 
Figure 6: Level of Index for the Services Industry

\author{
Wholesale Trade \\ Retail Trade \\ Accommodation \\ Food and Beverage Services \\ Road Transport \\ Rail Transport
}

Water, Pipeline and Other Transport

Air and Space Transport

Postal and Courier Pick-up and Delivery Service

Transport Support services and storage

Publishing (except Internet and Music Publishing)

Motion Picture and Sound Recording

Broadcasting (except Internet)

Internet Publishing and Broadcasting and.

Telecommunication Services

Library and Other Information Services

Finance

Insurance and Superannuation Funds

Auxiliary Finance and Insurance Services

Rental and Hiring Services (except Real Estate)

Ownership of Dwellings

Non-Residential Property Operators and Real Professional, Scientific and Technical Services Computer Systems Design and Related Services Building Cleaning, Pest Control, Administrative. Public Administration and Regulatory Services

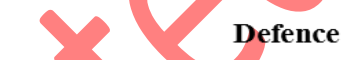

Public Order and Safety

Education and Training

Health Care Services

Residential Care and Social Assistance Services Heritage, Creative and Performing Arts

Sports and Recreation

Gambling

Automotive Repair and Maintenance Other Repair and Maintenance

Personal Services

Other Services
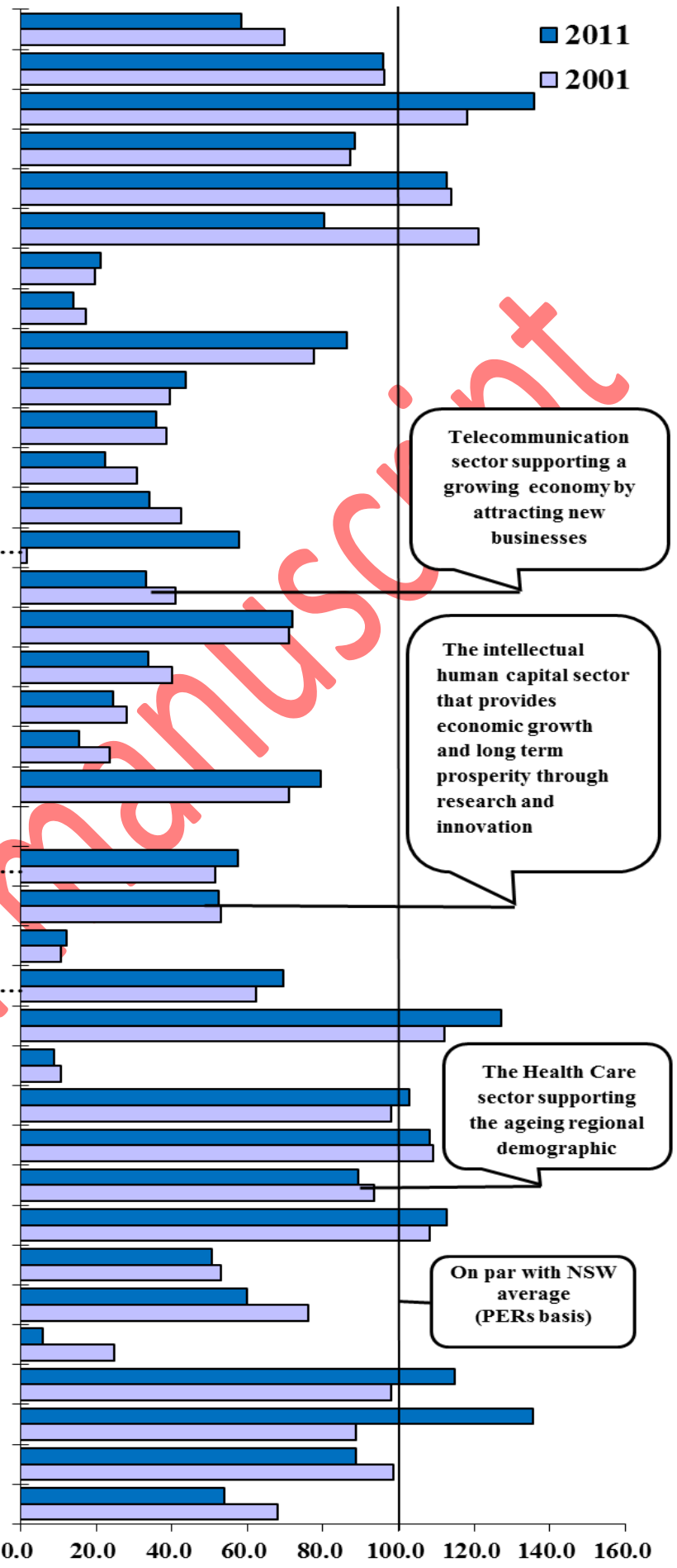

Index: NSW Average $=100.0$

Source and notes: Calculated as per methods from Australian Bureau of Statistics (2013a)

\title{
VI. DISCUSSION
}

There are a number of issues emanating from the above analysis which require further discussion. First, while GRP doubled from 2001 to 2011 there was little growth in the region's employment to 
population ratio. The underlying reason for this lack of overall poor employment-to-population growth is twofold: (i) the economy has structurally changed from a dependence on agriculture to mining, given mining is capital intensive and income-labour shares declined (Blackwell and Dollery, 2013; 2014); and (ii) the aging population of the region moving into retirement. In line with this structural shift in the economy, agricultural and forestry exports dwindled from 15 per cent in 2001 to 11 per cent in 2011 and continued to employ fewer people along with a continuing decline in agricultural productivity (Sheng, Mullen, \& Zhao, 2011). This structural shift reflects that which is experienced in other regional areas of Australia (Haslam McKenzie et al., 2013). While employment in the mining sector increased by approximately 160 per cent over the period, with its LQ increasing 25 per cent, the sector continues to employ only a small number of people compared to other sectors (Figure 4). This growing influence of the local mining industry in GRP gives rise to a number of questions concerning the industry's contribution to sustainable (social, economic and environmental) development in the region (Brueckner et al., 2013). One area of particular concern in the context of this study is that the industry has had considerable employment shedding in recent years since 2011 because of a shift from an investment to production phase (Barber et al., 2013).

Second, manufacturing, while dwindling as in other regional locations (Warren \& Gibson, 2012) remains important to the exports of the regional economy of the Central West and has a higher employment-to-export ratio than mining (Figure 4). Manufacturing of food, chemicals, building materials, petroleum, coal products and basic non-ferrous metal products were key sectors contributing to exports. Although these exports declined over the decade, they still contributed 20 per cent to regional exports and, combined with the mining, accounted for 60 per cent of exports in 2011. Furthermore, the success of the export base of a region is a key determining factor in the rate of regional growth with the nominal value of exports almost tripling over the 2001 to 2011 period, contributing to a 200 per cent increase in the region's trade surplus. In stark contrast to its employment contribution, mining contributed the most to exports.

Third, a notable feature of this analysis is that the structural change within the region appears not to have greatly affected the region's mix of industrial diversity, even with the increased activity of mining. Despite a greater dependence on mining there is no evidence of increasing regional specialisation in comparison to NSW. This runs contrary to the Krugman's (1991) theory of regional economic development through specialisation and can be explained by mining contributing significantly to employment income leakage from the region.

Fourth and extending the previous point, there are more people commuting into the region for employment than commuting out because of the increased activity in mining. Commuting workers bring leakage of income from the regional economy and forgone growth. Despite this leakage, commuting workers may bring added skills and expertise to the local workforce and bring extra expenditure to the region through accommodation, transport, retail, and entertainment sectors. This would support any future renewal in the tourism sector. 
Fifth, an important consideration is that as the population of the Central West continues to age, and with an already significantly higher proportion of residents aged 40 plus, health care services will be in strong demand, but are in short supply. The short supply is reflected in the lower than average service delivery ratio which exhibited a decline from 2001 to 2011 (Figure 6).

Sixth, the current Central West growth pattern is tending to reinforce its current strengths in mining and mining-related industries. However, looking to the future, a sharp reversal in commodity prices has an obvious implication for employment and regional economic growth. Therefore, identifying the appropriate mix of regional diversity is critical to the development of the region. Those sectors, which could foster innovation and technology through research and development, are telecommunications, and professional, technical and scientific services which were found to be underserviced. Keeping abreast of scientific discoveries, emerging technologies and animal health strategies would be ideal areas of investment (Miles, et al,. 2006; Woodhouse, 2006). Similarly, improved telecommunications services would assist in attracting new businesses, employment and local growth (Bandias \& Ram Vemuri, 2005). Also notworthy are high ratios in the public administration and regulatory services sector so this could imply some degree of inefficient resource provision. The redirection of these resources to other underserviced areas within the region may lead to an increase to the area's overall economic efficiency.

Seventh, a related issue is that productivity growth, which has been the main driver of agricultural output in Australia for more than 50 years (Sheng, Mullen \& Zhao, 2011), has been steadily falling, since the mid-1990s, due primarily to stagnating investment in public agricultural research and development (R\&D) (Fuglie \& Toole, 2014; Pardey, Roseboom \& Beintema, 1997). Targeted investment in R\&D of this kind could also provide renewed productivity growth.

Eighth, wine tourism has obvious appeal as a potential growth industry and in 2012 almost one million people visited a winery within the region (Tourism Research Australia, 2012), and that most of these visitors were domestic, broadening the range of visitors to include international visitors presents an opportunity, given the recent depreciation of the Australian dollar. The new market of Chinese tourists holidaying in Australia was found to more likely purchase Australian wine than other tourists (Bowe, Lockshin, Rungie, \& Lee, 2015). We suggest that a tourism marketing strategy promoting the region's wine, food and other distinctive attributes should play an integral role in future regional development planning, drawing on a range of stakeholders (Tkaczynski, Rundle-Thiele, \& Beaumont, 2009).

Finally, the nature of the research undertaken in this study lends itself to comparative analysis. Similar studies of other regional areas would provide valuable information for regional economic development and planning; helping to ensure that Australia's economic growth is not merely confined to the highly populated cities and towns, but shared more broadly across regional areas in Australia and overseas. 


\section{CONCLUSION}

The regional economy in this study only slightly became more industrially diverse over the decade 2001 to 2011, despite the strong growth in the mining industry. Generally, there has been an overall improvement in unemployment across the region over the decade due to the mining industry. However, the growth of this industry has subsequently declined and this source of growth is not expected to continue at the rates previously experienced. The economic activity of the Central West region has shifted from one reliant on agriculture to one reliant on mining but mining is not contributing to local economic resilience through employment diversification.

As an alternative to mining, the identifiable sectors of the economy through which future investment may help to underpin the region's economic viability are telecommunications, and professional, technical and scientific services. In addition, a tourism marketing strategy promoting the region's food, wine and other distinctive attributes may play an integral role in future regional development planning.

\section{Acknowledgements}

The authors are grateful to a number of anonymous reviewers of earlier drafts of this manuscript and to Dr [insert name] of [insert University] who prepared the map of the Central West Region. Funding that enabled this research includes an Australian Postgraduate Award and a NSW Rural Assistance Authority scholarship.

\section{REFERENCES}

Archer, B., \& Fletcher, J. (1996). The economic impact of tourism in the Seychelles. Annals of tourism research, 23(1), 32-47.

Attaran, M. (1986). Industrial diversity and economic performance in US areas. The Annals of Regional Science, 20(2), 44-54.

Australian Bureau of Statistics. (2013a). 1981-2011 Industry of Employment by Local Government Areas (POW), Census of Population and Housing, Persons Count Based on Usual Place of Residence. Canberra: ABS.

Australian Bureau of Statistics. (2013b). 3235.0 - Population by Age and Sex, Regions of Australia, 2012. Canberra: ABS.

Bandias, S., \& Ram Vemuri, S. (2005). Telecommunications infrastructure facilitating sustainable development of rural and remote communities in Northern Australia. Telecommunications Policy, 29(2), 237-249.

Banks, G. (2005). Structural reform Australian-style:lessons for others? Canberra: Productivity Commission.

Barber, J., Penney, K., Shael, T., Cowling, S., \& Nicholson, P. (2013). Resources and Energy Major Projects October 2013. Canberra: Bureau of Resources and Energy Economics.

Beer, A., \& Clower, T. (2009). Specialisation and growth: evidence from Australia's regional cities. Urban Studies, 46(2), 369-389.

Blackwell, B. D., \& Dollery, B. 2014. The impact of mining expenditure on remote communities in Australia: The Ranger uranium mine and the Tanami gold mine in the Northern Territory. Australasian Journal of Regional Studies, 20(1), 68-97. Accessed 19 Aug 2014 from: http://www.anzrsai.org/assets/Uploads/PublicationChapter/Blackwell-and-Dollery-final.pdf 
Blackwell, B. D., Fischer, A., McFarlane, J., \& Dollery, B. (2015) Mining and other industrial contributions to employment leakage in the Northern Territory, Australia. Journal of Developing Areas, Special Issue from ABSS Sydney Conference (in-print).

Bowe, J., Lockshin, L., Rungie, C., \& Lee, R. (2015). Wine and Tourism: A Good Blend Goes a Long Way. Ideas in Marketing: Finding the New and Polishing the Old. Springer International Publishing, 309-312.

Bradley, R., \& Gans, J. S. (1998). Growth in Australian cities. Economic Record, 74(226), 266-278.

Brueckner, M., Durey, A., Mayes, R., \& Pforr, C. (2013). The mining boom and Western Australia's changing landscape: Towards sustainability or business as usual? Rural Society, 22(2), 111124.

Carson, D. (2011). Skilled Labour Migration Flows to Australia's Northern Territory 2001-2006: Beyond Periphery? Australian Journal of Labour Economics, 14(1), 15-33.

Caselli, F., \& Michaels, G.( 2013). Do Oil Windfalls Improve Living Standards? Evidence from Brazil. American Economic Journal: Applied Economics, American Economic Association, 5(1), 208-238.

Delgado, M., Porter, M. E., \& Stern, S. (2014). Clusters, convergence, and economic performance. Research Policy, 43(10), 1785-1799.

Dennis, R. (2012). The use and abuse of economic modelling in Australia Users' guide to tricks of the trade. The Australia Institute, Canberra.

Diniz, F., \& Upadhyay, V. (2010). Productive specialization and regional development at State level in India. Regional Science Inquiry Journal, 2(2), 105-118.

Dissart, J. C. (2003). Regional economic diversity and regional economic stability: research results and agenda. International Regional Science Review, 26(4), 423-446.

Dixon, R., \& Freebairn, J. (2009). Trends in Regional Specialisation in Australia. Australasian Journal of Regional Studies, 15(3), 281-296.

Dubé, J., \& Polèse, M. (2014). Resource Curse and Regional Development: Does Dutch Disease Apply to Local Economies? Evidence from Canada. Growth and Change, 46(1),38-57.

Duranton, G., \& Puga, D. (2000). Diversity and specialisation in cities: why, where and when does it matter?. Urban studies, 37(3), 533-555.

Fleming, D. A., \& Measham, T. G. (2015). Local economic impacts of an unconventional energy boom: the coal seam gas industry in Australia. Australian Journal of Agricultural and Resource Economics, 59(1), 78-94.

Fuglie, K. O., \& Toole, A. A. (2014). The evolving institutional structure of public and private agricultural research. American journal of agricultural economics, 97(1), aat107.

Haig, R. M. (1926). Toward an Understanding of the Metropolis. The Quarterly Journal of Economics, 40(3),402-434.

Halseth, G. (2005). Resource town transition: Debates after closure. Rural Change and Sustainability: Agriculture, the Environment and Communities. CABI Publishing, Wallingford, Oxfordshire, 326-342.

Haslam McKenzie, F., Rolfe, J., Hoath, A., Buckley, A., \& Greer, L. (2013). Regions in Transition: Uneasy Transitions to a Diversified Economy involving Agriculture and Mining: Final Report 978-1.Prepared for CSIRO Minerals Down Under Flagship. Canberra: Curtin University, Central Queensland University and CSIRO.

Horridge, M. (2003). ORANI-G: A Generic Single-Country Computable General Equilibrium Model. Centre of Policy Studies:Monash University. Edition prepared for the Practical GE Modelling Course, June 23-27, 2003

Hvidt, M. (2013). Economic diversification in GCC countries: Past record and future trends. London: London School of Economics.

Iammarino, S., \& McCann, P. (2013). Multinationals and economic geography: location, technology and innovation. Cheltenham: Edward Elgar Publishing.

Jensen, R. C., \& West, G. (1986). Input-Output for Practitioners: Theory and Applications.No 1. Canberra: Australian Govt. Pub. Service.

Johnson, T. G. (2001). The rural economy in a new century. International Regional Science Review, 24(1), 21-37. 
Keniry, J. (2003). Regional Business: A Plan for Action. Canberra: Commonwealth Department of Transport and Regional Services.

Koo, J. (2007). Determinants of localized technology spillovers: role of regional and industrial attributes. Regional Studies, 41(7), 995-1011.

Krugman, P. (1991). Increasing Returns and Economic Geography. Journal of Political Economy, 99(3), 483-499.

Malizia, E. E., \& Ke, S. (1993). The influence of economic diversity on unemployment and stability. Journal of Regional Science, 33(2), 221-235.

Martin, R., \& Sunley, P. (2003). Deconstructing clusters: chaotic concept or policy panacea? Journal of Economic Geography, 3(1), 5-35.

McManus, P., Walmsley, J., Argent, N., Baum, S., Bourke, L., Martin, J., \& Sorensen, T. (2012). Rural Community and Rural Resilience: What is important to farmers in keeping their country towns alive?. Journal of Rural Studies, 28(1), 20-29.

Measham, T. G., McKenzie, F. H., Moffat, K., \& Franks, D. (2013). Reflections on the role of the resources sector in Australian economy and society during the recent mining boom. Rural Society, 22(2), 184-194.

Miles, R. L., Marshall, C., Rolfe, J., \& Noonan, S. (2006). The attraction and retention of professionals to regional areas. Australasian Journal of Regional Studies, 12(2), 129152.Mitchell, R., Charters, S., \& Albrecht, J. N. (2012). Cultural systems and the wine tourism product. Annals of tourism research, 39(1), 311-335.

Nelson, A. C., Drummond, W. J., \& Sawicki, D. S. (1995). Exurban industrialization: Implications for economic development policy. Economic Development Quarterly, 9(2), 119-133.

North, D. C. (1955). Location theory and regional economic growth. The Journal of Political Economy, 63(3)243-258.

Organisation for Economic Co-operation and Development.(2013). Economic Policy Reforms: Going For Growth 2013. Paris: OECD.

Pardey, P. G., Roseboom, J., \& Beintema, N. M.(1997). Investments in African agricultural research. World Development, 25(3), 409-423.

Porter, M. (2000). Location, competition, and economic development: Local clusters in a global economy. Economic development quarterly, 14(1), 15-34.

Productivity Commission (2005). Trends in Australian agriculture, Research Paper, Canberra.

Regional Australia Institute. (2013). Insight: Australia's Regional Competitiveness Index - Economic Diversification and the Competitiveness of Regional Australia. Canberra: RAI.

Rodríguez-Pose, A., \& Gill, N. (2006). How does trade affect regional disparities?. World Development, 34(7), 1201-1222.

Rodrik, D. (2008). One economics, many recipes: globalization, institutions, and economic growth. New Jersey:Princeton University Press.

Rolfe, J., Miles, B., Lockie, S., \& Ivanova, G. (2007). Lessons from the social and economic impacts of the mining boom in the Bowen Basin 2004-2006. Australasian Journal of Regional Studies ,13(2), 134-153.

Salomon, Jlan. Telecommunications, cities and technological opportunism.The Annals of Regional Science,30(1),75-90.

SGS Economics and Planning. (2008). Future Directions for Regional NSW. Sydney: Planning Institute of Australia. http://www.planning.org.au/documents/item/1494

Sheng, Y., Mullen, J. D., \& Zhao, S. (2011). A turning point in agricultural productivity: consideration of the causes. Canberra: ABARES.

Sheng, Y., Zhao, S., Nossal, K., \& Zhang, D. (2015). Productivity and farm size in Australian agriculture: reinvestigating the returns to scale. Australian Journal of Agricultural and Resource Economics, 59(1), 16-38.

Shields, M. L. (2003). Using Employment Data to Better Understand Your Local Economy: Tool 3. Use Location Quotients to Identify Local Strengths, Opportunities, and Industry Clusters. Pennsylvania State University, State College, PA.

Siegel, P. B., Johnson, T. G., \& Alwang, J. (1995). Regional economic diversity and diversification. Growth and Change, 26(2), 261-284. 
Smith, S. M., \& Gibson, C. M. (1988). Industrial diversification in nonmetropolitan counties and its effect on economic stability. Western Journal of Agricultural Economics,13(2), 193-201.

Thomas, G., Hamilton, D., \& Stephens, M. Agricultural competitiveness white paper submission. Agricultural Science, 26(1), 25-29.

Thompson, S., \& Maginn, P. (2012). Planning Australia: an overview of urban and regional planning. Sydney: Cambridge University Press.

Tisdell, C. A. (2013). Competition, Diversity and Economic Performance. Cheltenham: Edward Elgar Publishing.

Tkaczynski, A., Rundle-Thiele, S. R., \& Beaumont, N. (2009). Segmentation: A tourism stakeholder view. Tourism management, 30(2), 169-175.

Tourism Research Australia. (2012). International Visitor Survey and National Visitor Survey, Canberra: TRA.

Trendle, B. (2006). Regional economic instability: the role of industrial diversification and spatial spillovers. The Annals of Regional Science, 40(4), 767-778.

Trendle, B. (2009). The determinants of population and employment growth in small Queensland regions. Economic Analysis and Policy, 39(2), 295-307.

Valadkhani, A. (2003). Using input-output analysis to identify Australia's high employment generating industries. Australian Bulletin of Labour, 29(3), 199-217.

Van Oort, F., de Geus, S., \& Dogaru, T. (2014). Related variety and regional economic growth in a cross-section of European urban regions. European Planning Studies, (ahead-of-print), 1-18.

Warren, A., \& Gibson, C. (2012). Manufacturing on the move?. Beyond the high dollar in the debate about making things in Australia-the case of the Australian surfboard industry-AUSCCER Discussion Paper, (2012/2), 1-18.

Wilson, L. J. (2004). Riding the Resource Roller Coaster: Understanding Socioeconomic Differences between Mining Communities. Rural Sociology, 69(2), 261-281.

Woodhouse, A. (2006). Social capital and economic development in regional Australia: A case study. Journal of Rural Studies, 22(1), 83-94. 